\title{
Involvement of a Cell Envelope Component of Escherichia coli in the Early Stages of Infection with Bacteriophage $\phi X 174$
}

\author{
Yoshihiro Mano, Tatsuya Kawabe, Tohru Komano \\ and Kazumori YAZAKI* \\ Laboratory of Biochemistry, Department of Agricultural Chemistry, \\ Kyoto University, Kyoto 606, Japan \\ *Hepatitis Division, Tokyo Metropolitan Institute of Medical Science, \\ Honkomagome, Bunkyo-ku, Tokyo 113, Japan
}

Received December 10, 1981

\begin{abstract}
Envelope fraction I prepared from a $\phi$ X174 sensitive host, KD4301, showed a strong eclipsing activity, while the lipopolysaccharide (LPS) fraction showed a weak activity. The eclipsing activity in envelope fraction I was sensitive to heat treatment, while that in the LPS fraction was insensitive. When the complete phage particles (114S) were treated with envelope fraction I, the eclipsed particles (70S) and a rapidly sedimenting component were obtained, but when they were treated with LPS, only 70 S eclipsed particles were obtained. Electron microscopic observation showed that there were two types of eclipsed particles formed on treatment with fraction I; in one of them phage DNA was extruded from the phage particles as a thick bundle, and in the other more than $95 \%$ of the phage DNA was extruded from the phage particles. The rapidly sedimenting component was the membrane-eclipsed particle complex. LPS gave only one type of eclipsed particles in which DNA was extruded as a thick bundle. These results indicate that a heat labile component in the cell envelopes other than LPS is involved in the extrusion of $\phi$ X174 DNA.
\end{abstract}

Bacteriophage $\phi \times 174$ is an icosahedral particle carrying a spike at each of the vertices. $\phi$ X174 multiplication starts with infection. The early stages of infection with $\phi$ X174 can be separated into three major stages: attachment, eclipsing and complete penetration of phage DNA. ${ }^{1)}$ The attachment stage is the process of reversible binding between phage particles and lipopolysaccharide (LPS) receptor sites. At $15^{\circ} \mathrm{C}$ or below, only the attachment stage occurs and $100 \%$ of the attached phages can be recovered from the cell surface by elution with borate-EDTA buffer as fully infective particles, complete phage particles. ${ }^{1)}$ At normal temperatures (about $37^{\circ} \mathrm{C}$ ), the attached phages rapidly undergo an irreversible conformational change (eclipse). The elipse stage is the process of irreversible binding between phage particles and the cell envelopes. Some of the altered phage particles are spontaneously detached from the cell surface as non-infectious particles, while the remainder are more tightly bound to the cell surface. ${ }^{1)}$ The altered phage particles lose their infectivity for fresh cells and are defined as eclipsed particles. ${ }^{1)}$ The complete phage particles have a sedimentation value of 114 , while the eclipsed particles have 70 , because the DNA is partially extruded from the phage capsid. ${ }^{1)}$ Subsequently, $\phi X 174$ single-stranded (SS) DNA penetrates into the cells through the cell envelopes and is converted to the duplex parental replicative form (RF) DNA. ${ }^{1)}$ The cell envelopes possess the activity to convert the attached phages to eclipsed particles (eclipsing activity). ${ }^{2)}$

The cell envelopes of Enterobacteriaceae ( $E$. coli, S. typhimurium) consist of an outer membrane, a peptidoglycan-lipoprotein complex and an inner membrane. ${ }^{3)}$ The main structural components of the outer membrane are proteins, LPS and phospholipids. The outer membrane acts as the initial permeability barrier of the cells and also as a receptor for bacteriophages and bacteriocins. ${ }^{4 \sim 14)}$ Some bac- 
teriophages (T1, T5, T6, $\phi 80$ and $\lambda$ ) recognize the outer membrane protein as the receptor, ${ }^{4,10,13)}$ others (TuIa, TuIb, TuII ${ }^{\star}$, $\mathrm{K} 3$ and $\mathrm{T} 4)$ recognize the outer membrane protein-LPS complex as the receptor. ${ }^{5,7,9,11,14)}$ Recently, we have shown that the host dnaP gene product, which is a membrane protein and necessary for the initiation of DNA replication in E. coli, participates in phage elipising and in phage DNA penetration in vivo in normal $\phi$ X174 infection. ${ }^{15)}$

In this paper it is reported that a heat labile component in the cell envelopes other than LPS is involved in the extrusion of $\phi \times 174$ DNA during the early stages of infection and that the phage DNA seems to be extruded from a single spike of the capsid as a thick bundle.

\section{MATERIALS AND METHODS}

Bacteria and phage strains. E. coli KD4301 (uvrA6, thy, $p h x A^{\mathrm{s}}, \operatorname{trp}(\mathrm{am}), \sup -126$, his, rif $\left.^{\mathrm{r}}, \mathrm{malA}\right)$ and KD48 (uvrA6, phx $\left.A^{\mathrm{s}}, \operatorname{trp}(a m), \operatorname{tyr}(a m), \sup D, \operatorname{rif} f^{\mathrm{f}}, \operatorname{malA}\right)$, a permissive host for the $\phi \mathrm{X} 174$ amber mutant, were used. $^{15)}$ KD4301 and KD48 were $\phi X 174$-sensitive derivatives of the E. coli $\mathrm{K} 12$ strain.

$\phi \mathrm{X} 174 a m 3$ is a lysis-defective amber mutant in gene $\mathrm{E}$.

Media and buffers. PPG medium was the modified peptone-glucose (PG) medium ${ }^{16)}$ and consisted of polypeptone, $20 \mathrm{~g} ; \mathrm{NaCl}, 2.5 \mathrm{~g} ; \mathrm{KCl}, 2.5 \mathrm{~g}$; and glucose, $2 \mathrm{~g}$ per liter. The $\mathrm{pH}$ of the medium was adjusted to 7.6 with $\mathrm{NaOH}$. Borate buffer was as described previously. ${ }^{15)}$ Tris$\mathrm{HCl}$ buffer was $10 \mathrm{~mm}$ tris(hydroxymethyl)aminomethane (Tris)-hydrochloride ( $\mathrm{pH}$ 7.6). Tris- $5 \mathrm{~mm} \mathrm{Ca}, \mathrm{Mg}$ buffer was Tris- $\mathrm{HCl}$ buffer containing $5 \mathrm{mM} \mathrm{CaCl}_{2}$ and $5 \mathrm{~mm}$ $\mathrm{MgCl}_{2}$.

Chemicals. ${ }^{32} \mathrm{P}-\mathrm{Phosphoric}$ acid $(53 \mathrm{mCi} / \mathrm{ml}$, carrier free) was purchased from the Japan Atomic Energy Institute.

Preparation of ${ }^{32} \mathrm{P}$-labeled $\phi X 174 a \mathrm{~m} 3 .{ }^{32} \mathrm{P}$-labeled $\phi \mathrm{X} 174 a \mathrm{am} 3$ was prepared by the procedures reported by Knippers et al. ${ }^{17)}$ The specific activity of the purified phage was approximately $3 \times 10^{5} \mathrm{cpm} / \mathrm{ml}\left(3 \times 10^{10} \mathrm{PFU} / \mathrm{ml}\right)$.

Preparation of cell envelopes. The preparation of cell envelopes was carried out by slight modification of the procedures described by Osborn et al. ${ }^{18)}$ E. coli KD4301 cells were grown with shaking to $1 \times 10^{8}$ cells per $\mathrm{ml}$ at $37^{\circ} \mathrm{C}$ in 1 liter of PPG medium containing $50 \mu \mathrm{g} / \mathrm{ml}$ of thymine. The cells were collected by centrifugation at room temperature for $30 \mathrm{~min}$ at $3,000 \times g$, suspended in $10 \mathrm{ml}$ of Tris- $\mathrm{HCl}$ buffer containing $0.75 \mathrm{M}$ sucrose, and chilled on ice. Lysozyme was added to the cell suspension to a final concentration of $80 \mu \mathrm{g} / \mathrm{ml}$, and the mixture was allowed to stand at $2^{\circ} \mathrm{C}$ for $2 \mathrm{~min}$. Tris- $\mathrm{HCl}$ buffer containing $1.5 \mathrm{~mm}$ ethylenediaminetetraacetic acid disodium salts (EDTA) $(20 \mathrm{ml})$ was gradually added to the mixture at $2^{\circ} \mathrm{C}$ over a period of 8 to $10 \mathrm{~min}$.

The spheroplasts formed were broken by sonication in an ice bath. The unbroken cells were removed by centrifugation at $2^{\circ} \mathrm{C}$ for $20 \mathrm{~min}$ at $1,500 \times \mathrm{g}$. The supernatant was dialyzed against 2 liters of Tris- $5 \mathrm{~mm} \mathrm{Ca}, \mathrm{Mg}$ buffer at $4^{\circ} \mathrm{C}$ for $15 \mathrm{hr}$. The cell envelopes in the dialysate were collected by centrifugation at $4^{\circ} \mathrm{C}$ for $1 \mathrm{hr}$ at $100,000 \times g$ in an RPS40T rotor of a Hitachi ultracentrifuge and suspended in $4 \mathrm{ml}$ of Tris- $\mathrm{HCl}$ buffer containing $0.25 \mathrm{M}$ sucrose (Envelope fraction I). Envelope fraction I contained $5 \mathrm{mg} / \mathrm{ml}$ of LPS and $8 \mathrm{mg} / \mathrm{ml}$ of protein, but did not contain viable cells. Envelope fraction I diluted appropriately with Tris- $5 \mathrm{~mm} \mathrm{Ca}, \mathrm{Mg}$ buffer was used in the following experiment.

Preparation of LPS. LPS of E. coli KD4301 was prepared by the procedures of Galanos et al. ${ }^{19)}$ Lyophilized LPS was weighed out and dissolved in Tris- $\mathrm{HCl}$ buffer containing $1.5 \mathrm{~mm}$ EDTA at a final concentration of $5 \mathrm{mg}$ / $\mathrm{ml}$ (LPS fraction). LPS fraction diluted appropriately with Tris- $5 \mathrm{~mm} \mathrm{Ca}, \mathrm{Mg}$ buffer was used in the following experiment.

Heat treatment of intact cells, envelope fraction I and LPS fraction. E. coli KD4301 cells were grown with shaking to $1 \times 10^{8}$ cells $/ \mathrm{ml}$ at $37^{\circ} \mathrm{C}$ in $10 \mathrm{ml}$ of $\mathrm{PPG}$ medium containing $1 \mathrm{mM} \mathrm{CaCl}{ }_{2}$ and $50 \mu \mathrm{g} / \mathrm{ml}$ of thymine. The cells were collected by centrifugation at room temperature for $15 \mathrm{~min}$ at $3,000 \times g$, washed twice with an equal volume of Tris- $5 \mathrm{~mm} \mathrm{Ca}, \mathrm{Mg}$ buffer, and resuspended in $10 \mathrm{ml}$ of the same buffer. The cell suspension was divided into four portions $(0.9 \mathrm{ml}$ each), which were heated at $100^{\circ} \mathrm{C}$ for $0,15,30$ and $60 \mathrm{~min}$, respectively, and then allowed to stand at room temperature.

Five portions $(0.9 \mathrm{ml}$ each) of envelope fraction I were heated at $100^{\circ} \mathrm{C}$ for $0,5,10,30$ and $60 \mathrm{~min}$, respectively, and then allowed to stand at room temperature.

Two portions $(0.9 \mathrm{ml}$ each) of LPS fraction were heated at $100^{\circ} \mathrm{C}$ for 0 and $60 \mathrm{~min}$, respectively, and then allowed to stand at room temperature.

Assay for phage eclipse kinetics. The cell suspension, envelope fraction I or PLS fraction was incubated at $37^{\circ} \mathrm{C}$ for $30 \mathrm{~min}$. $\phi \mathrm{X} 174 a \mathrm{~m} 3(0.1 \mathrm{ml})$ was added to the mixture $(0.9 \mathrm{ml})$ at a titer of $3 \times 10^{7}$ plaque forming units (PFU) per $\mathrm{ml}$ followed by incubation at $37^{\circ} \mathrm{C}$. At various intervals, eclipsing was monitored. The procedures were essentially the same as those described by Newbold and Sinsheimer. ${ }^{20)}$ 
Neutral sucrose density gradient analysis of phage conformational change. Envelope fraction I $(90 \mu \mathrm{l})$ or LPS fraction $(90 \mu \mathrm{l})$ was incubated at $37^{\circ} \mathrm{C}$ for $10 \mathrm{~min}$. $\phi \mathrm{X} 174 \mathrm{am} 3$ (10 $\mu \mathrm{l})$ or ${ }^{32} \mathrm{P}$-labeled $\phi \mathrm{X} 174 \mathrm{am} 3(10 \mu \mathrm{l})$ was added to each fraction and the mixture $(100 \mu \mathrm{l})$ was incubated at $37^{\circ} \mathrm{C}$ for $30 \mathrm{~min}$ and then chilled on ice. An ice-cold Tris- $\mathrm{HCl}$ bufer containing $100 \mathrm{~mm}$ EDTA $(100 \mu \mathrm{l})$ was added to the mixture. The sample was layered onto $3.8 \mathrm{ml}$ of a linear 5 to $20 \%(\mathrm{w} / \mathrm{v})$ sucrose gradient formed over a $0.5-\mathrm{ml}$ shelf of $80 \%(\mathrm{w} / \mathrm{v})$ sucrose in $50 \mathrm{~mm}$ Tris- $\mathrm{HCl}$ buffer $(\mathrm{pH} 7.6)$ containing $0.5 \mathrm{M} \mathrm{NaCl}$ and $3 \mathrm{~mm}$ EDTA. This gradient was centrifuged for $2.5 \mathrm{hr}$ at $28,000 \mathrm{rpm}$ at $4^{\circ} \mathrm{C}$ in an PRS40T2 rotor of a Hitachi $65 \mathrm{P}$ preparative ultracentrifuge. After centrifugation, fractions were collected from the bottom of the tube. When ${ }^{32} \mathrm{P}$-labeled phage was used, tritonscintillator was added to each fraction and the radioactivity was measured with a Beckman liquid scintillation counter. When cold phage was used, the desired fractions were dialyzed against $1000 \mathrm{ml}$ of $50 \mathrm{~mm}$ Tris- $\mathrm{HCl}$ buffer (pH 7.6) containing $0.5 \mathrm{M} \mathrm{NaCl}$ and $3 \mathrm{~mm}$ EDTA at $4^{\circ} \mathrm{C}$ for $12 \mathrm{hr}$.

Electron microscopy. The interaction between $\phi \mathrm{X} 174 a m 3$ and envelope fraction I or LPS fraction was examined with an electron microscope JEOL $100 \mathrm{C}$ by the procedures of Yazaki. ${ }^{21)}$

Analytical methods. The amount of protein was determined by the procedure of Lowry et al. ${ }^{22)}$ The amount of LPS was estimated from the 2-keto-3-deoxyoctulosonic acid content, which was determined by the procedure described by Osborn et al. ${ }^{18)}$

\section{RESULTS}

Eclipsing activities of envelope fraction $I$ and LPS of E. coli KD4301

$\phi X 174 a m 3$ was incubated with envelope fraction I or LPS fraction prepared from $E$. coli KD4301 and phage eclipsing was monitored. Envelope fraction I showed strong eclipsing activity. The eclipsing activity in envelope fraction I increased with incubation time (Fig. 1) and with increasing concentration of envelope fraction I (Fig. 2). On the other hand, the LPS fraction showed weak activity. Phage eclipsing proceeded at a reduced rate with incubation time (Fig. 1) and with increasing concentration of the LPS fraction (Fig. 2).

These results indicate that envelope fraction I contains a component showing strong eclipsing activity other than LPS.

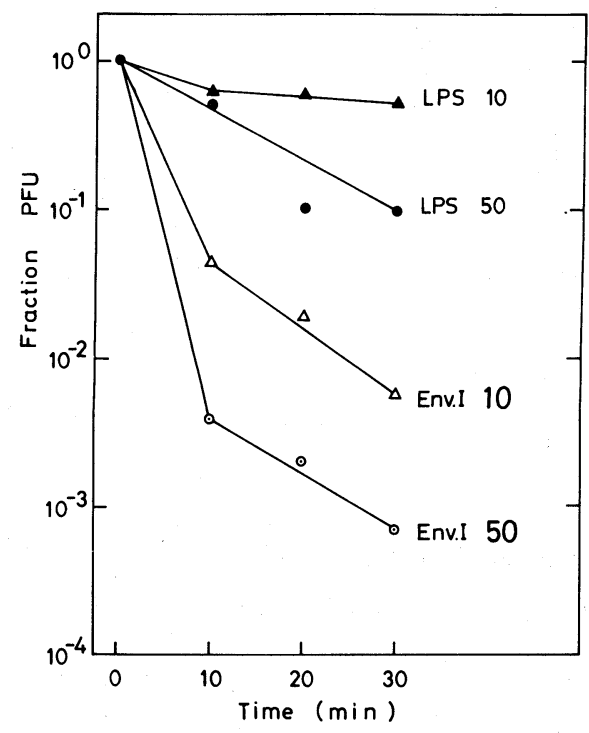

FIG. 1. Effect of Incubation Time with Envelope Fraction I or LPS Fraction on Eclipse Kinetics of $\phi X 174 a m 3$.

Envelope fraction I or LPS fraction, suspended in Tris$5 \mathrm{~mm} \mathrm{Ca}, \mathrm{Mg}$ buffer, was incubated at $37^{\circ} \mathrm{C}$ for $30 \mathrm{~min}$. Eclipsing was monitored at $0,10,20$ and $30 \mathrm{~min}$ after addition of the phage. $0.1 \mathrm{ml}$ sample was removed from the reaction mixture, diluted 100 -fold with borate buffer containing $10 \mathrm{~mm}$ EDTA (borate-EDTA buffer) saturated with chloroform at $0^{\circ} \mathrm{C}$, and stirred vigorously with a Vortex mixer for $30 \mathrm{sec}$. Further Eclipsing was prevented by the low temperature and EDTA. The uneclipsed particles and eclipsed particles were eluted from the cell surface with borate-EDTA buffer. The titer of phage in borate-EDTA buffer represents the residual and uneclipsed phages. The amount of LPS in envelope fraction I was determined by the procedure described by Osborn et al. ${ }^{18}$ ) and the concentration of LPS in envelope fraction I was adjusted to the same concentration as that of the LPS fraction for comparison.

Symbols: $\odot-\odot$, Env. I 50, envelope fraction I containing $50 \mu \mathrm{g} / \mathrm{ml}$ of LPS; $\triangle-\triangle$, Env. I 10, envelope fraction I containing $10 \mu \mathrm{g} / \mathrm{ml}$ of LPS; - - LPS 50, LPS fraction containing $50 \mu \mathrm{g} / \mathrm{ml}$ of LPS; $\boldsymbol{\Delta}-\mathbf{\Delta}$, LPS 10 , LPS fraction containing $10 \mu \mathrm{g} / \mathrm{ml}$ of LPS.

\section{Heat inactivation of eclipsing activity in intact} cells, envelope fraction I and LPS fraction

Intact cells, envelope fraction I or LPS fraction suspended in Tris- $5 \mathrm{~mm} \mathrm{Ca}, \mathrm{Mg}$ buffer was heated at $100^{\circ} \mathrm{C}$ for various periods of time, infected with $\phi \mathrm{X} 174 \mathrm{am} 3$, and then phage eclipsing was monitored.

Figure 3 shows the inactivation of eclipsing 


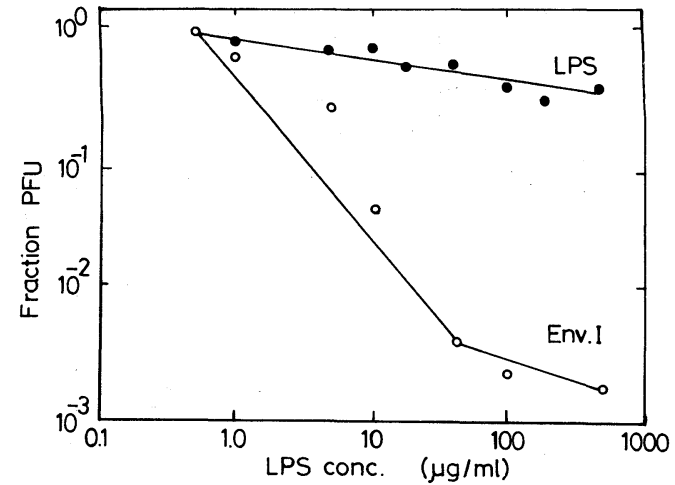

FIG. 2. Effect of Concentration of Envelope Fraction I or LPS Fraction on Eclipse Kinetics of $\phi$ X174am3.

Envelope fraction I or LPS fraction, suspended in Tris$5 \mathrm{~mm} \mathrm{Ca}, \mathrm{Mg}$ buffer, was incubated at $37^{\circ} \mathrm{C}$ for $30 \mathrm{~min}$. Eclipsing was monitored at 0 and $10 \mathrm{~min}$ after addition of $\phi \mathrm{X} 174 a \mathrm{~m} 3$. The experimental procedure is described in Materials and Methods, and the legend to Fig. 1.

Symbols: $\bigcirc-\mathrm{O}$, envelope fraction $\mathrm{I} ;-\mathbf{O}$, LPS fraction.

activity in intact cells by heat treatment. The eclipsing activity decreased remarkably with increasing time of heat treatment, but was not completely lost even when heat treatment was carried out for more than $60 \mathrm{~min}$ at $100^{\circ} \mathrm{C}$ (data not shown). Figure 4 shows the inactivation of eclipsing activity in envelope fraction I on heat treatment. Envelope fraction I contained $25 \mu \mathrm{g} / \mathrm{ml}$ of LPS and $40 \mu \mathrm{g} / \mathrm{ml}$ of protein. The results were similar to those for intact cells. When envelope fraction I was heated, the eclipsing activity decreased remarkably, but weak elipsing activity still remained in envelope fraction I (Fig. 4).

On the other hand, when LPS fraction was heated at $100^{\circ} \mathrm{C}$ for $60 \mathrm{~min}$, the eclipsing activity was not influenced (Fig. 5). The LPS fraction showed weak elipsing activity even in the presence of a high concentration of LPS $(200 \mu \mathrm{g} / \mathrm{ml})$.

These results indicate that both a heat labile component and a heat stable component (LPS) are involved in the expression of the eclipsing activity, and that the heat labile component, which is contained in intact cells and envelope fraction $I$, is essential for the expression of strong eclipsing activity.

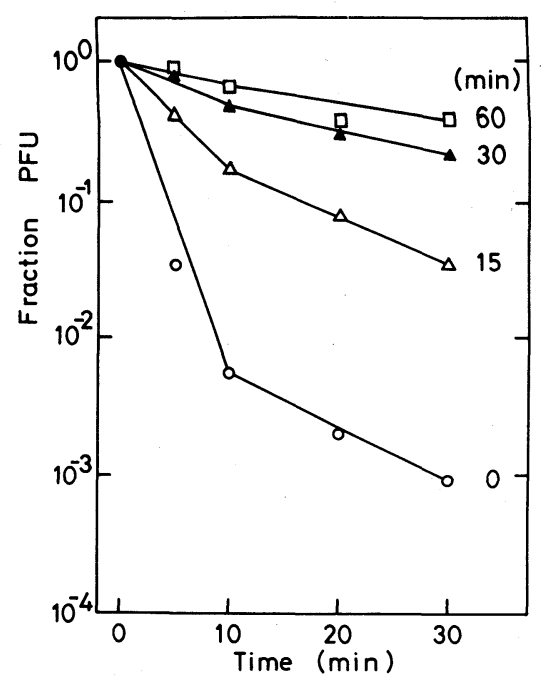

FIG. 3. Heat Inactivation of the Eclipsing Activity in Intact Cells.

Heat treatment of intact cells was performed as described in Materials AND Methods. Eclipsing was monitored at $0,5,10,20$ and $30 \mathrm{~min}$ after addition of $\phi \times 174$ am3. The experimental procedure is described in the legend to Fig. 1. Symbols: $\bigcirc-\bigcirc$, control (without heat treatment); $\triangle-\triangle$, heat treatment for $15 \mathrm{~min} ; \boldsymbol{\Delta}-\mathbf{\Delta}$, heat treatment for $30 \mathrm{~min}$; $\square-\square$, heat treatment for $60 \mathrm{~min}$.

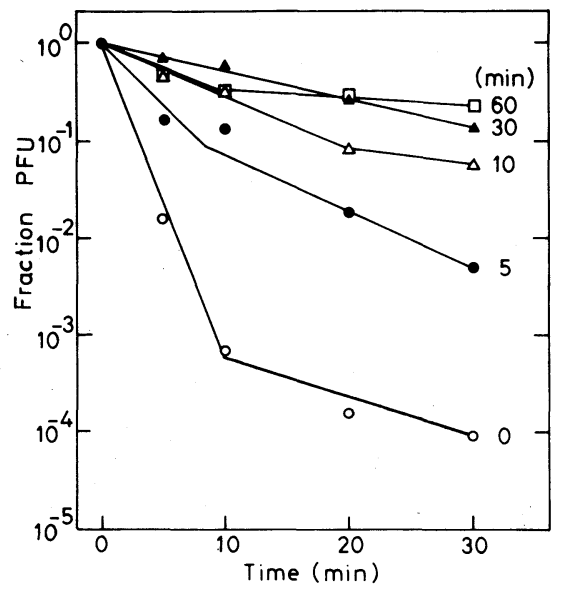

FIG. 4. Heat Inactivation of the Eclipsing Activity in Envelope Fraction I.

Heat treatment of envelope fraction I was performed as described in MATERIALS AND METHODS. Envelope fraction I containing $25 \mu \mathrm{g} / \mathrm{ml}$ of LPS and $40 \mu \mathrm{g} / \mathrm{ml}$ of protein was used. Eclipsing was monitored as described in the legend to Fig. 3.

Symbols: $\bigcirc-\bigcirc$, control (without heat treatment); -1 , heat treatment for $5 \mathrm{~min} ; \triangle-\triangle$, heat treatment for $10 \mathrm{~min} ; \boldsymbol{\Delta}-\boldsymbol{\Delta}$, heat treatment for $30 \mathrm{~min} ; \square-\square$, heat treatment for $60 \mathrm{~min}$. 


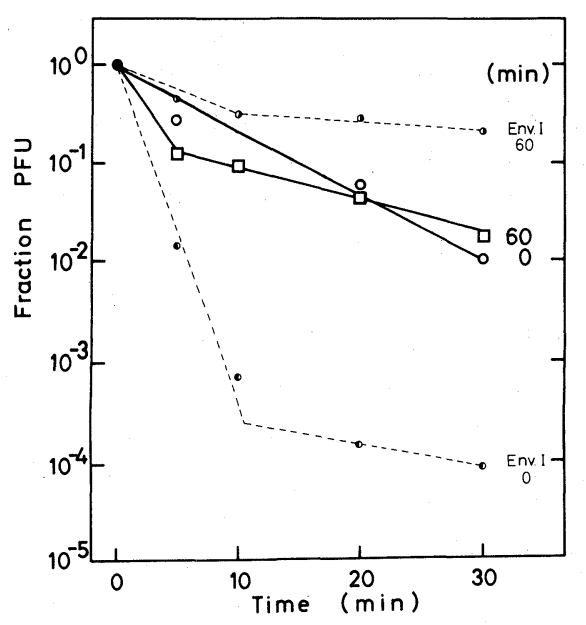

FIG. 5. Comparison of Heat Inactivation of the Eclipsing Activity in Envelope Fraction I with that in the LPS Fraction.

Heat treatment of the LPS fraction was performed as described in Materials AND Methods. Eclipsing was monitored as described in the legend to Fig. 3. Heat inactivation of the eclipsing activity in the LPS fraction (LPS concentration; $200 \mu \mathrm{g} / \mathrm{ml}$ ) is compared with that in envelope fraction I (LPS concentration; $25 \mu \mathrm{g} / \mathrm{ml}$ ).

Symbols: $\bigcirc-\bigcirc$, control in LPS fraction (without heat treatment); $\square-\square$, heat treatment for $60 \mathrm{~min}$ in LPS fraction; 1 -- 1 , control in envelope fraction I (without heat treatment; --- heat treatment for $60 \mathrm{~min}$ in envelope fraction $\mathrm{I}$.

Sucrose density gradient analysis of conformational change in phage particles after treatment with envelope fraction I and LPS fraction

The difference in eclipsing activity between envelpe fraction I and LPS fraction was examined by sucrose density gradient analysis, as it is known that conformational change in phage particles (conversion of a $114 \mathrm{~S}$ intact phage particle into a $70 \mathrm{~S}$ eclipsed particle) is observed when $\phi \mathrm{X} 174$ is incubated with host cells or cell envelopes. ${ }^{1,23)}$ The results are shown in Fig. 6. When ${ }^{32} \mathrm{P}$-labeled $\phi \mathrm{X} 174$ am 3 was treated with envelope fraction $\mathrm{I}$ at $37^{\circ} \mathrm{C}$ for $30 \mathrm{~min}$, three radioactive peaks were observed which cosedimented with the $70 \mathrm{~S}$ component, the $114 \mathrm{~S}$ component and a more rapidly sedimenting component (fraction numbers 1 to 5) than 114S (Fig. 6A). When the phage was treated with LPS fraction at $37^{\circ} \mathrm{C}$ for $30 \mathrm{~min}$, two

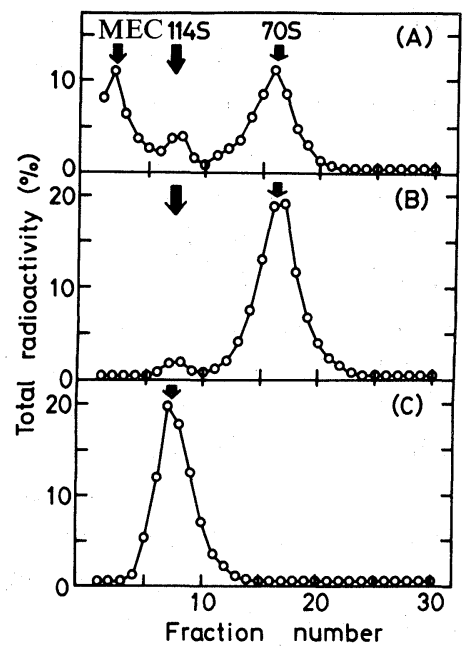

FIG. 6. Sucrose Density Gradient Analysis of Conformational Change of the Phage after Treatment with Envelope Fraction I or LPS Fraction.

The conditions were described in MATERIALS AND Methods. Arrows indicate the peak positions of the membrane-eclipsed particle complex, 114S (intact phage particles) and $70 \mathrm{~S}$ (eclipsed particles), respectively. (A) envelope fraction I (LPS concentration; $250 \mu \mathrm{g} / \mathrm{ml}$ ); (B) LPS fraction (LPS concentration; $250 \mu \mathrm{g} / \mathrm{ml}$ ); (C) intact phage particles as control.

radioactive peaks were observed which cosedimented with the $70 \mathrm{~S}$ component and the $114 \mathrm{~S}$ component (Fig. 6B). The component sedimenting more rapidly than $114 \mathrm{~S}$ was not observed with LPS treatment. Although 70S eclipsed particles were formed when $\phi \times 174$ was treated with envelope fraction I and LPS fraction (Figs. 6A and 6B), the component sedimenting more rapidly than $114 \mathrm{~S}$ was formed only when the phage was treated with envelope fraction I (Fig. 6A). Since this complex is considered to be an intermediate of the infecting phage, the DNA of which is penetrated into the cell through cell envelopes after phage eclipsing, this complex was named the membrane-eclipsed particle complex (MEC).

These results indicate that a heat labile component possesses the ability to form eclipsed particles and the membrane-eclipsed particle complex; on the other hand, a heat stable component (LPS) possesses the ability only to form eclipsed particles. 
Electron microscopic observation of conformational change in phage particles after treatment with envelope fraction I or LPS fraction

Conformational change in phage particles after treatment with envelope fraction I or LPS fraction was observed with an electron microscope. The results are shown in Fig. 7. Phage $\phi \mathrm{X} 174$ particles seemed to bind tightly to a small fragment of a membrane vesicle when treated with envelope fraction I (Figs. 7A, 7B and $7 \mathrm{C}$ ). The phage DNA was extruded from the phage capsid, and formed the complex with the membrane vesicle (Fig. 7A). The thickness of phage DNA indicated by the arrow in Fig. 7A was approximately $4 \mathrm{~nm}$, and corresponded to about twofold the thickness of phage SS DNA (according to the experimental conditions, the thickness of a SS DNA strand is taken as $1.8 \mathrm{~nm}^{21)}$ ). If the observed thickness of phage DNA was not due to the binding of phage proteins, $93 \%$ of the whole phage DNA would be extruded as a thick bundle of SS DNA. Phage particles bound to membrane vesicles were observed, but the extruded DNA was not visible as it seemed to be concealed in membrane vesicles (Fig. 7B). Even when eclipsed particles were eluted with EDTA from cell envelopes, they still associated with small membrane vesicles (Fig. 7C). This complex resistant to EDTA-elution is considered to be the membrane-eclipsed particle complex described above. $\phi \mathrm{X} 174$ was treated with envelope fraction I and the mixture was sedimented by sucrose density gradient centrifugation. After fractionation, several fractions in the neighbourhood of the 70S peak were dialyzed carefully and the $70 \mathrm{~S}$ component was visualized with an electron microscope (Figs. 7D and 7E). The 70S component was the eclipsed particle which was completely eluted with EDTA from cell envelopes. Two types of eclipsed particles were observed; one with the phage DNA extruded from the phage particle as a single thick bundle (Fig. 7D), and the other with more than 95\% of the whole phage DNA extruded from the phage particle as a thick bundle having branches whose thickness corresponded to more than twofold the thickness of phage SS DNA (Fig. 7E). In both cases the DNA extrusion was observed to occur at a single spike of the phage particle (Fig. 7E).

When the phage particles treated with LPS fraction were sedimented, fractionated and dialyzed carefully, the $70 \mathrm{~S}$ component obtained was eclipsed particles in which only a part of the phage DNA was extruded as a bundle (Fig. 7F).

Figure $7 \mathrm{G}$ shows intact phage particles having complete spikes.

These results indicate that phage particles are extremely changed in conformation on treatment with envelope fraction I having very strong eclipsing activity, and the extruded phage DNA binds to membrane vesicle to

FIG. 7. Electron Microscopic Observation of Conformational Change in Phage Particles after Treatment with Envelope Fraction I and LPS Fraction.

(A), (B) and (C): Envelope fraction I $(90 \mu \mathrm{l})$ was incubated at $37^{\circ} \mathrm{C}$ for $10 \mathrm{~min}$ and $\phi \mathrm{X} 174 \mathrm{am} 3$ (10 $\mu \mathrm{l}$, approximately $\left.10^{10} \mathrm{PFU} / \mathrm{ml}\right)$ was added to the fraction. The reaction mixture $(100 \mu \mathrm{l})$ (LPS concentration; $\left.5 \mu \mathrm{g} / \mathrm{ml}\right)$ was incubated at $37^{\circ} \mathrm{C}$ for $30 \mathrm{~min}$ and chilled on ice. An ice-cold Tris- $\mathrm{HCl}$ buffer containing $100 \mathrm{~mm}$ EDTA $(100 \mu \mathrm{l})$ was added to the reaction mixture. The sample was visualized by the procedures of Yazaki. ${ }^{21)}$ (D) and (E): After $\phi X 174 a m 3$ and envelope fraction I (LPS concentration; $250 \mu \mathrm{g} / \mathrm{ml}$ ) were incubated, the reaction was stopped by addition of EDTA as described above. The sample was layered onto a sucrose gradient and the gradient was centrifuged as described in MATERIALS AND METHODS. After fractionation, the desired fractions (several fractions in the neighbourhood of the $70 \mathrm{~S}$ peak) that corresponded to the radioactive distribution in Fig. 6A were dialyzed against $50 \mathrm{~mm}$ Tris- $\mathrm{HCl}$ buffer (pH 7.6) containing $0.5 \mathrm{M} \mathrm{NaCl}$ and $3 \mathrm{~mm}$ EDTA, and the 70S component was prepared carefully as described in MATERIALS AND METHODS. The sample was visualized by the procedures of Yazaki. ${ }^{21)}(\mathrm{F})$ : The procedures were essentially the same as those described in the legend to Fig. 7D and 7E except for using LPS fraction (LPS concentration; $250 \mu \mathrm{g} / \mathrm{ml}$ ) instead of envelope fraction I. (G): Control, the procedures were essentially the same as those described in the legend to Fig. 7A, 7B and 7C except for using Tris- $5 \mathrm{~mm} \mathrm{Ca}, \mathrm{Mg}$ buffer instead of envelope fraction I or LPS fraction. 


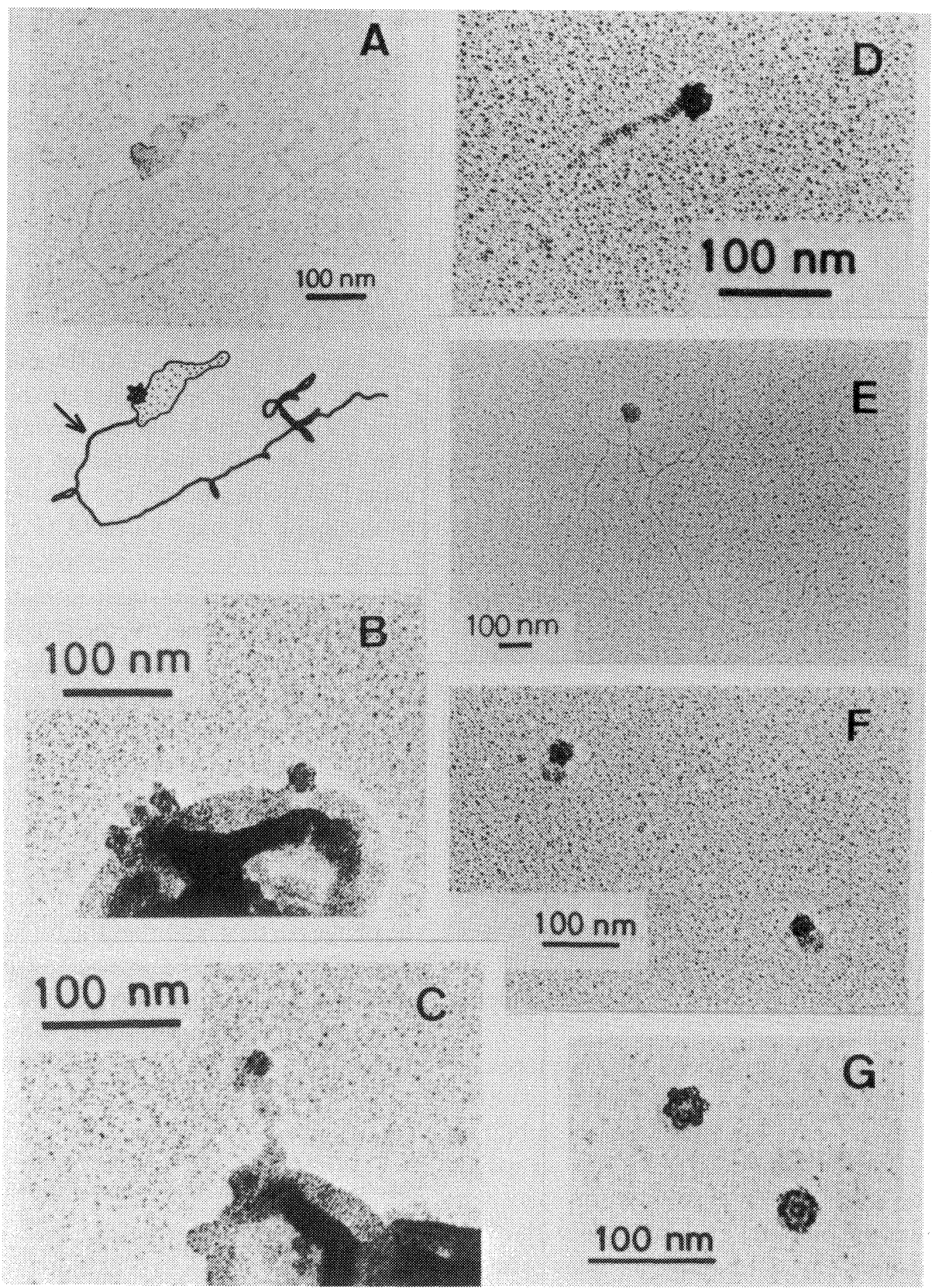

FIG. 7.

form the membrane-eclipsed particle complex, but the phage DNA was hardly extruded on treatment with LPS fraction having weak eclipsing activity. These results seems to also indicate that the DNA extrusion occurs at a single spike of the phage particle.

\section{DISCUSSION}

Lipopolysaccharide (LPS) is considered to be the receptor for bacteriophage $\phi \mathrm{X} 174$, since recognition by $\phi \times 174$ of LPS isolated from a sensitive strain of E. coli $\mathrm{C}$ or $S$. typhimurium is sufficient to inactivate the phage and to cause 
the conformational change of the phage into eclipsed particles. ${ }^{24,25)}$ But it has been reported that components other than LPS in the outer membrane are involved in the early stages of infection with $\phi \times 174 .^{15,23,26)}$

The cell envelopes of intact cells possess a native eclipsing activity. The eclipsing activity in envelope fraction I was very strong (Figs. 1 and 2), but decreased remarkably on heat treatment (Fig. 4). On the other hand, the eclipsing activity in LPS fraction was not influenced by heat treatment (Fig. 5). Therefore a heat labile component other than LPS might be involved in expression of the native eclipsing activity (Figs. 3 and 4).

The main structural components of cell envelopes are phospholipids, LPS, proteins and peptidoglycan. ${ }^{327)}$ Since peptidoglycan is stable on hot SDS treatment, ${ }^{28}$ the heat labile component seems to be a membrane protein or phospholipid. When envelope fraction I was treated with phospholipase, the eclipsing activity was not influenced (data not shown). Therefore, it seems that phospholipid is not the heat labile component involved in the expression of the strong eclipsing activity. In our previous report we suggested that one of the membtane proteins participates in phage eclipsing and phage DNA penetration. ${ }^{15}$ ) So the heat labile component seems to be a membrane protein.

The eclipsing activity in cell envelopes is influenced by detergents and divalent cations. When the cell envelope proteins are solubilized by treatment with detergents, the eclipsing activity is lost. ${ }^{2)}$. Cell envelopes (in particular the outer membrane) are stabilized with divalent cations by formation of ionic bridges between the negative charges within the outer membrane proteins ${ }^{29)}$ and the polysaccharide parts of LPS protruded from the surface of the outer membrane. ${ }^{30)}$ Divalent cations can also form a complex with lipids to alter their properties. ${ }^{31)}$ It is possible that electrostatic and hydrophobic interactions between LPS and membrane proteins affect the state of cell envelopes. ${ }^{32,33)}$ This evidence suggests that a suitable interaction between LPS and mem- brane proteins is essential for the expression of a native eclipsing activity.

The phage eclipse seems to proceed in two steps; the first step is triggered by LPS, which brings about the change of the capsid protein conformation, a small amount of DNA being extruded from a single spike (Figs. 6B and 7F), and the second step is the complete extrusion of phage DNA by the function of a membrane protein to form the membrane-eclipsed particle complex (Figs. 6A, 7A, 7D and 7E). The extruded phage DNA is a single thick bundle (Fig. 7D) or a thick bundle having branches (Fig. 7E), and the thickness of the extruded phage DNA corresponds to more than twofold the thickness of phage SS DNA (Figs. 7A, 7C, $7 \mathrm{D}$ and $7 \mathrm{E}$ ). It has been reported that phage DNA can form several stable intrastrand basepairs $^{34)}$ and that gene $J$ protein (core protein) of $\phi \times 174$ serves to condense (fold) the phage DNA during assembly of phage proteins. ${ }^{35,36)}$ The folding of phage DNA seems to be stimulated by formation of intrastrand base-pairs in $\phi X 174$ SS DNA. Electron microscopic observation suggests that the phage DNA extruded as a thick bundle (Fig. 7D) reflects the state of the highly folded phage DNA encapsidated in the phage particle, and that the branches of the phage DNA (Fig. 7E) correspond to the part of intrastrand base-pairs. A possible role of the heat labile membrane protein would be unfolding of the phage DNA from the capsid.

Acknowledgment. This work was supported in part by a Grant-in-Aid for Scientific Research from the Ministry of Education, Science and Culture Japan.

\section{REFERENCES}

1) J. E. Newbold and R. L. Sinsheimer, J. Mol. Biol., 49, 49 (1970).

2) Y. Mano and T. Komano, Agric. Biol. Chem., 46, 631 (1982).

3) J. W. Costerton, J. M. Ingram and K. J. Cheng, Bacteriol. Rev., 38, 87 (1974).

4) V. Braun, K. Schaller and H. Wolff, Biochim. Biophys. Acta, 323, 87 (1973).

5) D. B. Datta, B. Arden and U. Henning, J. Bacteriol., 131, 821 (1977).

6) R. D. DiMasi, J. C. White, C. A. Schnaitman and C. Bradbeer, J. Bacteriol., 115, 506 (1973). 
7) H. Furukawa, H. Yamada and S. Mizushima, J. Bacteriol., 140, 1071 (1979).

8) A. A. Lindberg, Annu. Rev. Microbiol., 27, 205 (1973).

9) P. A. Manning, A. Puspurs and P. Reeves, $J$. Bacteriol., 127, 1080 (1976).

10) P. A. Manning and P. Reeves, Biochem. Biophys. Res. Comm., 71, 466 (1976).

11) N. Mutoh, H. Furukawa and S. Mizushima, $J$. Bacteriol., 136, 693 (1978).

12) T. Nakae and H. Nikaido, J. Biol. Chem., 250, 7359 (1975).

13) S. Szmeleman and M. Hofnung, J. Bacteriol., 124, 112 (1975).

14) L. Van Alphen, L. Havekes and B. Lugtenberg, FEBS Lett., 75, 285 (1977).

15) Y. Mano, H. Sakai and T. Komano, J. Virol., 30, 650 (1979).

16) C. Wada and T. Yura, Genetics, 77, 199 (1974).

17) R. Knippers, W. O. Saliver, J. E. Newbold and R. L. Sinsheimer, J. Mol. Biol., 39, 641 (1969).

18) M. J. Osborn, J. E. Gander, E. Parisi and J. Carson, J. Biol. Chem., 247, 3962 (1972).

19) C. Galanos, O. Lüderitz and O. Westphal, Eur. J. Biochem., 9, 245 (1969).

20) J. E. Newbold and R. L. Sinsheimer, J. Virol., 5, 427 (1970).

21) K. Yazaki, J. Virol. Methods, 2, 159 (1981).

22) O. H. Lowry, N. J. Rosebrough, A. L. Farr and R. J.
Rnadall, J. Biol. Chem., 193, 265 (1951).

23) P. D. Neuwald, J. Virol., 15, 497 (1975).

24) N. L. Incardona and L. Selvidge, J. Virol., 11,775 (1973).

25) S. M. Jazwinski, A. A. Lindberg and A. Kornberg, Virology, 66, 268 (1975).

26) S. M. Jazwinski and A. Kornberg, Proc. Natl. Acad. Sci. U.S.A., 72, 3863 (1975).

27) J. M. DiRienzo, K. Nakamura and M. Inouye, Ann. Rev. Biochem., 47, 481 (1978).

28) V. Braun and U. Sieglin, Eur. J. Biochem., 13, 336 (1970).

29) B. Witholt, H. van Heerikhuizen and L. D. Leij, Biochim. Biophys. Acta, 443, 534 (1976).

30) L. Leive, J. Biol. Chem., 243, 2372 (1968).

31) D. Chapman, J. Urbina and K. M. Keough, J. Biol. Chem., 249, 2512 (1974).

32) A. Steir and E. Sackman, Biochim. Biophys. Acta, 311, 400 (1973).

33) G. B. Warren, P. A. Toon, N. J. M. Birdsall, A. G. Lee and J. C. Metcalfe, Proc. Natl. Acad. Sci. U.S.A., 71, 622 (1974).

34) T. D. Edlind and G. M. Ihler, J. Mol. Biol., 142, 131 (1980).

35) D. K. Freymeyer II, P. R. Shank, M. H. Edgell, C. A. Hutchison III and T. C. Vanaman, Biochemistry, 16, 4550 (1977).

36) P. R. Shank, C. A. Hutchison III and M. H. Edgell, Biochemistry, 16, 4545 (1977). 